\title{
Water Absorption by Hydrogel Using Fertilizers
}

\author{
José F. Sobrinho ${ }^{1} \&$ Francisca Edineide L. Barbosa ${ }^{1}$ \\ ${ }^{1}$ Mestrado Acadêmico em Geografia, Vale do Acaraú State University - UVA, Ceará, Brazil \\ Correspondence: José F. Sobrinho, Mestrado Acadêmico em Geografia, Vale do Acaraú State University - UVA, \\ Ceará, Brazil. Tel: 55-85-99-797-2626. E-mail: falcao.sobral@gmail.com
}

Received: February 20, 2020

Accepted: March 24, 2020

Online Published: May 5, 2020

doi:10.5539/enrr.v10n2p26

URL: https://doi.org/10.5539/enrr.v10n2p26

\begin{abstract}
It was sought, in this research, to evaluate the effects of fertilizer solutions on water retention by hydrogel as well as if the application methods and fertilizers affect water retention when the hydrogel is added to the soil. In laboratory works (experiment 1), the completely randomized design was used taking into account four treatments: distilled water; Urea (UR - $2.0 \mathrm{~g} \mathrm{~L}^{-1}$ ) and Magnesium Sulfate + Monoammonium Phosphate (MS + MAP - 2.0 $\mathrm{g} \mathrm{L}^{-1}$ each). Regarding the experiment 2, considering soil columns, a $2 \times 3 \times 2$ factorial was used, corresponding to two hydrogel application methods: dry and mixed to the soil or diluted in water and concentrated in the center of the column; three fertilizer solutions: distilled water, UR $\left(2.0 \mathrm{~g} \mathrm{~L}^{-1}\right)$ and MS + MAP $\left(2.0 \mathrm{~g} \mathrm{~L}^{-1}\right.$ each $)$ with two cycles and three repetitions. An additional witness (hydrogel free) was also added. Total water volume absorbed by hydrogel, volume stored in the soil after each cycle, $\mathrm{pH}$ and electrical conductivity (EC) of leached solutions were all analyzed. The MS solution was the one who impacted the most the water absorption by the hydrogel, principally when the hydrogel was not present in the soil. The $\mathrm{pH}$ and $\mathrm{EC}$ of leached solutions evidenced the fertilizer solutions salinity.
\end{abstract}

Keywords: Electrical Conductivity, Fertilizers, Polymer, Salinity, Water Retention

\section{Introduction}

Hydrogels are tridimensional polymers chains (Glowińska et al., 2019) composed of various materials, among which are acrylics, such as acrylamide, acrylic and methacrylic acid (Dąbrowska \& Lejcuś, 2012); lignocellulosic biomass derivates (cellulose, xylan and lignin); carboxymethylcellulose, starch and $\mathrm{SiO}_{2}$ nanoparticles (Kalinoski \& Shi, 2019; Pathak \& Kumar, 2017), amongst others. However, acrylic and acrylamide based hydrogels are the most successfully widespread (Dąbrowska \& Lejcuś, 2012) and affordable to agricultural purposes.

The agricultural application of hydrogels is due to their capacity to absorb and retain water from ten percent to hundreds of times its dry weight and make it available for plants gradually, forming a gel capable of hydrating and releasing water for long periods as shown by different researches (Guilherme et al., 2018; Sartore et al., 2013; Moghadam et al., 2011).

Such characteristic may favor water retention in sandy and/or degraded soils, where less water is available, reduces crop water deficit and saves water (Pereira et al., 2018; Fajardo et al., 2013; El-Hady \& Wanas, 2012; Ruthrof et al., 2010). Therefore, plant production is favored in semi-arid and degraded areas.

Despite great perspectives about their use, hydrogels may have their water absorption potential reduced when fertilizers are used along, because of factors such as the interaction between fertilizers ions and polymers, the solution ionic force, temperature and pH (Głowińska et al., 2019; Azevedo et al., 2006; Johnson, 1984).

Thus, this research seeks to estimate the effects of different fertilizers solutions under the water retention by hydrogel, in a laboratory exploratory level, as well as evaluating how the hydrogel application methods and fertilizers affect the water retention when the hydrogel is in contact with the soil.

\section{Material and Methods}

This work was initially divided into two stages: the first one took place in the laboratory of soils and analysis of water for irrigation in the Instituto Federal do Ceará (IFCE) (Federal Institute of Ceará), Sobral Campus, which is located $240 \mathrm{~km}$ far from the state capital, Fortaleza. The second part was carried out in a greenhouse, also in IFCE. The climate, according to Köppen's classification, is the BShw', which declares rains from January to May and drought along the rest of the year. 
In the first stage, the effects of different fertilizer solutions in the hydrogel absorption capacity were analyzed, all of them undergoing the completely randomized design (CRD) with four treatments: controlling, with distilled water; Urea solution (UR - $2.0 \mathrm{~g} \mathrm{~L}^{-1}$ ); Magnesium Sulfate solution (MS - $2.0 \mathrm{~g} \mathrm{~L}^{-1}$ ) and Monoammonium Phosphate solution (MAP $-2.0 \mathrm{~g} \mathrm{~L}^{-1}$ ), having three repetitions each.

Still in this stage, the fertilizers correspondent to each treatment were diluted in distilled water (in the concentration of $2.0 \mathrm{~g} \mathrm{~L}^{-1}$ ), and they had, after 20 minutes, their $\mathrm{pH}$ and electrical conductivity (EC) measured, using a CG1800 conductivity meter and a $\mathrm{pH}$ meter, respectively.

After that, $1.1 \mathrm{~L}$ of each solution was added to glass beakers containing $1.0 \mathrm{~g}$ of the Forth hydrogel (trade name), weighed on a FA2104N precision balance. 15 minutes later, enough time for the hydrogel to absorb as much solution as possible, the mixture was filtered on a $0.0425 \mathrm{~mm}$ mesh sieve, the excess of drained solution measured in a $1.0 \mathrm{~L}$ test tube and the volume was subtracted from the initial value $(1.1 \mathrm{~L})$ in order to obtain the total volume of solution retained by the hydrogel.

In the second experiment, the design was a $2 \times 3 \times 2$ factorial, which corresponded respectively to two hydrogel application methods, being in the first the dry mixed hydrogel (dehydrated) in the soil, and in the second, the hydrogel diluted in water and concentrated in the center of the soil column; three different solutions are: controlling (distilled water), UR solution (2.0 $\left.\mathrm{g} \mathrm{L}^{-1}\right)$ and MS solution + MAP $\left(2.0 \mathrm{~g} \mathrm{~L}^{-1}\right.$ each), with two hydration and dehydration cycles and five repetitions. Besides that, an additional witness (hydrogel free) was used, where distilled water was added, thus making up thirty-five treatments.

For the experiment conduction, thirty-five soil columns were set up (using 2.0 L PET bottles), each one containing $700 \mathrm{~g}$ of sieved sand collected from the surface layer in an area from the Universidade Estadual Vale do Acaraú (UVA) (Vale do Acaraú State University) in Sobral, Ceará. The soil chemical characteristics used were as follow: $\mathrm{pH}$ (water) $=8.0 ; 487.76 \mathrm{mg} \mathrm{kg}^{-1}$ of P; $31.58 \mathrm{~g} \mathrm{~kg}^{-1}$ of M.O.; $13.9 \mathrm{cmol}_{\mathrm{c} \mathrm{kg}}{ }^{-1}$ of CTC; $100 \%$ of V; and 11.3; 1.5 ; 0.665 and $0.435 \mathrm{cmol}_{\mathrm{c}} \mathrm{kg}^{-1}$ of $\mathrm{Ca}^{2+}, \mathrm{Mg}^{2+}, \mathrm{K}^{+}$and $\mathrm{Na}^{+}$, respectively, and clay texture class.

In fifteen of those bottles, the soil was mixed with $1.0 \mathrm{~g}$ of the (dry) hydrogel. A hole was drilled in other fifteen bottles that already had soil inside them and, soon after, a hydrogel previously diluted in distilled water was added in them. The other four bottles received only soil.

A container was placed in each column to collect the drained solution aiming at determining the leached volume as well as collecting the $\mathrm{pH}$ and $\mathrm{EC}$ measures.

The fertilizer solutions were subsequently prepared, just like in the first experiment, and they had their $\mathrm{pH}$ and EC measured before their application too. $1.0 \mathrm{~L}$ of the solution was added in each column in the first cycle, whereas $0.7 \mathrm{~L}$ was added in the second cycle after twenty-seven days.

After twelve hours that the solutions had been applied, the drained volume from each one of the columns was collected and measured in a $500 \mathrm{ml}$ test tube. The $\mathrm{pH}$ and $\mathrm{EC}$ of each sample were then determined. To determine the solution volume stored in the soil, the total solution value added in each cycle was subtracted by the value drained.

All of the analyzed parameters underwent an analysis of normality and later an analysis of variance (ANOVA). In reason of the meaningfulness by the $\mathrm{F}$ test, the data of both experiments were analyzed taking into consideration the Tukey test (5\%). The data of the second experiment were yet submitted to the Dunnett test at a 5\% probability level (bilateral) with the objective of evaluating the additional witness. All the statistical analyses mentioned here were carried out with the aid of the software Assistat.

\section{Results and Discussion}

The data of the hydrogel absorption capacity added to the fertilizer solutions were statistically different $(p>1 \%)$, being the magnesium sulfate solution in a concentration of $2 \mathrm{~g} \mathrm{~L}^{-1}$ the one that affected the most its absorption, since it promoted the hydrogel total swelling with only $34 \mathrm{ml}$ of the solution per gram (g) of polymer (Figure 1), what represents an average increase of only 34 times its dry weight.

The MAP solution affected negatively the hydrogel absorption capacity too, which caused the absorption of only $177 \mathrm{ml}$ of solution per $\mathrm{g}$ of hydrogel (Figure 1). This value corresponds to an increase of 177 times its dry weight, being 216 times lower in comparison to the controlling treatment, which used distilled water and whose absorption was $393 \mathrm{ml}$ per $\mathrm{g}$ of the hydrogel.

Urea, among the fertilizers, was the one that affected the less the hydrogel capacity to absorb water. It made possible the increase of 353 times its dry weight and did not differ statistically from the controlling treatment (Figure 1), despite in absolute terms, the latter showed better results. 


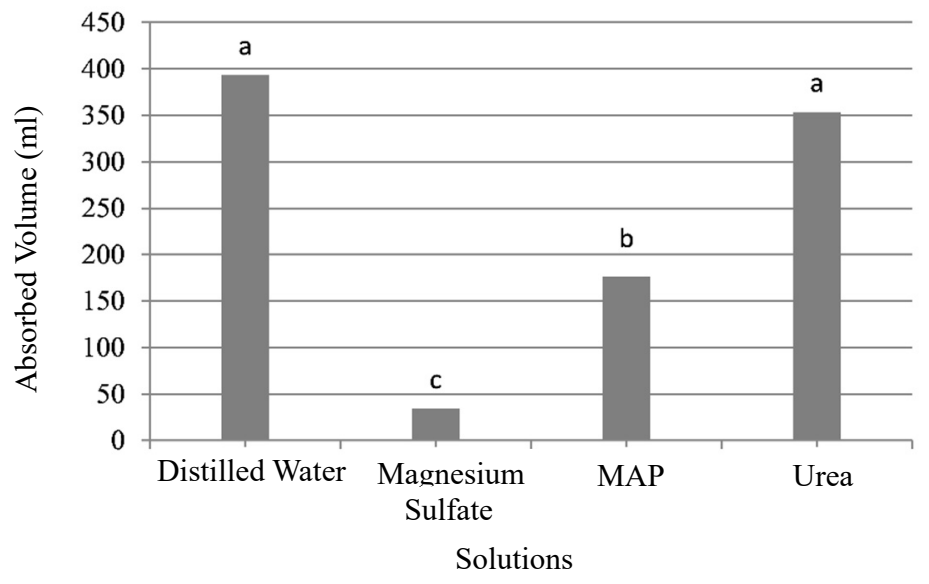

Figure 1. The volume of water absorbed by the hydrogel added of different fertilizer solutions

Note. MAP= Monoammonium Phosphate.

The negative effect on the absorption capacity of hydrogel with the application of sulfate solutions was yet observed by Azevedo et al. (2006), Bowman et al. (1990) and Johnson (1984). For the magnesium sulfate applied in the same concentration used in the experiments, Azevedo et al. (2006) found a $32.9 \mathrm{~g} \mathrm{~g}^{-1}$ retention, which is close to the value found in the experiments.

According to these authors, the salinity of the solution is what explains this effect, since the electrical conductivity of the hydrogel solution plus fertilizers tested by them was $2.4 \mathrm{mS} \mathrm{cm}^{-1}$, higher than that observed in distilled water (controlling treatment) that was close to zero. In this study, only the EC of the fertilizers solutions verified, before being mixed with the hydrogel and, even so, the EC values were 1.74 and $0.004 \mathrm{mS} \mathrm{cm}^{-1}$, for the magnesium sulfate solution and distilled water, respectively, indicating that there was an increase in salinity with the addition of the fertilizer.

In addition to it, after 24 hours of swelling with distilled water, the maximum retention was $287.2 \mathrm{~g}$ for each $\mathrm{g}$ of the dry hydrogel, which is lower than the value found in the experiments for 15 minutes after the swelling. Such a result is possibly due to the differences in product manufacturing since they are from different brands.

The fact of the solution salinity be the principal reason for the reduction of the volume absorbed by the hydrogel can be explained by the interference of salts in crosslinking level (from acrylic acid) that are responsible for keeping the long acrylamide chain together and determine the polyacrylamide behavior, so that the more connections there are, the greater the reduction in water retention capacity (Wang \& Gregg, 1990).

Regarding MAP and urea, the studies of Bowman et al. (1990) showed that hydration of commercial polyacrylamide polymers with anions of any valence and urea do not interfere in their water absorption capacity, unlike what occurs for the mono and divalent cations $\mathrm{Ca}^{2+}, \mathrm{Mg}^{2+}$ and $\mathrm{K}^{+}$and $\mathrm{NH}^{+4}$, respectively. This was verified during this work, urea solution did not affect water absorption by hydrogel, although the opposite occurs for the solution with MAP, which is disassociated when in contact with the anion phosphate (PO4-3). It is worth noting that in the composition of MAP, there are ammonium cations $\left(\mathrm{NH}^{+}\right)$that may be responsible for the reduction of water absorption by the hydrogel to the detriment of the phosphate anion.

The results cited above suggest that the addition of hydrogel without fertilizers provides greater water retention than when it is added with fertilizers. Nevertheless, the use of urea and anionic fertilizers can be prioritized to the detriment of those which are cationic.

It is important, however, that fieldwork is conducted, since when on the ground, other factors are active and may demonstrate different results as will be noted below.

For the second experiment, the analysis of variance presented in Table 1 showed, in the case of the volume of solution stored in the soil, a significant effect only of the cycle alone.

For $\mathrm{pH}$ and $\mathrm{EC}$, there was an isolated effect for fertilizer solutions and cycle as well as the interactions between the factors: fertilizer solutions and cycle, in the case of $\mathrm{pH}$ and $\mathrm{EC}$, and for the interaction: application method $\mathrm{x}$ cycle, in the case of $\mathrm{pH}$. There was also statistical significance between the additional witness and the other treatments, both for $\mathrm{pH}$ and EC. 
Regardless of the hydrogel application method and the solutions applied, the volume stored in the soil was lower in the second cycle, with an average difference of $26.8 \mathrm{ml}$ per treatment (Figure 2A).

For the EC of drainage solutions, it was observed that in both cycles, larger EC was observed in the soils added of magnesium sulfate solution + MAP. Differences also occurred between the EC of the first and second cycle, in the treatments with distilled water and MS + MAP solution (Figure 2B), and for the treatments added of MS + MAP solution occurred the increase of the EC from 1.3 to $1.9 \mathrm{mS} \mathrm{cm}^{-1}$, while for distilled water occurred the reduction of the EC in the second cycle.

Table 1. Analysis of variance (ANOVA) for the volume of solution stored in the soil, $\mathrm{pH}$ and electrical conductivity (EC)

\begin{tabular}{|c|c|c|c|c|c|c|c|}
\hline Variation Sources & GL & \multicolumn{6}{|c|}{ Average Square } \\
\hline Application Method & 1 & 3920,4167 & ns & 0,0005 & ns & 0,0193 & ns \\
\hline Fertilizers & 2 & 4666,2500 & ns & 13,6680 & $* *$ & 8,2079 & $* *$ \\
\hline Cycles & 1 & 10800,4167 & * & 8,3701 & $* *$ & 0,1471 & $* *$ \\
\hline Application Method x Fertilizers & 2 & 145,4167 & ns & 0,1661 & ns & 0,0366 & ns \\
\hline Application Method x Cycle & 1 & 70,4167 & ns & 0,7370 & $* *$ & 0,0249 & ns \\
\hline Fertilizers x Cycle & 2 & 3252,9167 & ns & 3,3223 & $* *$ & 0,9541 & ** \\
\hline Application Method x Fertilizers x Cycle & 2 & 1545,4167 & ns & 0,0821 & ns & 0,0337 & ns \\
\hline Factor $\mathrm{x}$ Additional Treatment + Controlling & 1 & 8104,8214 & $*$ & 0,0019 & ns & 1,5193 & $* *$ \\
\hline Additional Treatment x Controlling & 1 & 810,0000 & ns & 3,0360 & $* *$ & 0,1567 & $* *$ \\
\hline Treatments & 13 & 3302,0055 & & 3,5864 & $* *$ & 1,5640 & $* *$ \\
\hline Residue & 56 & 1792,3214 & & 0,0633 & & 0,0132 & \\
\hline Total & 69 & & & & & & \\
\hline $\mathrm{CV}(\%)$ & & 11,7 & & 3,4 & & 14,1 & \\
\hline
\end{tabular}

Note. GL= grau de liberdade
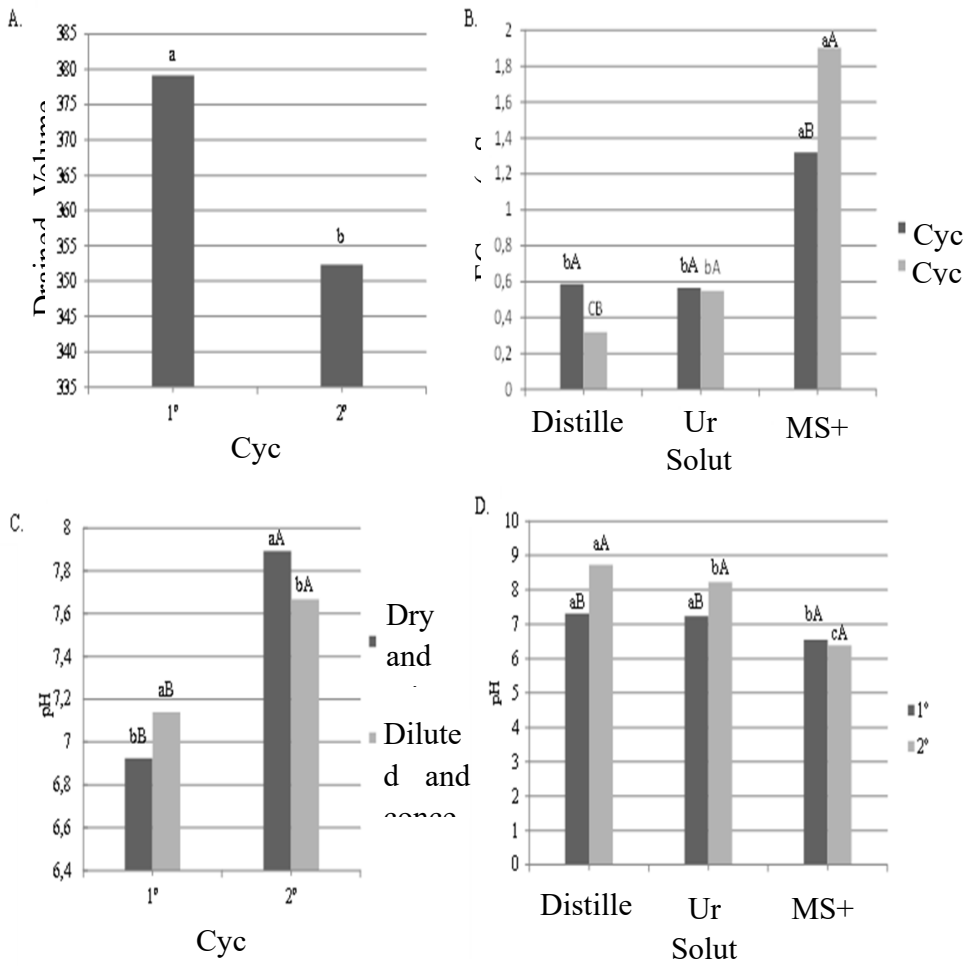

Figure 2. Stored volume x cycle (A); Fertilizer solutions x cycle (B); Hydrogel application method x cycle (C) and fertilizer solutions $\mathrm{x}$ cycle for the $\mathrm{pH}$ of solutions drained from the soil columns (D)

Note. $\mathrm{MS}+\mathrm{MP}=$ Magnesium Sulfate + Monoammonium Phosphate. 
For the $\mathrm{pH}$ in the first cycle, higher values occurred in the treatments that the hydrogel was diluted and concentrated in the center of the soil column, while in the second cycle occurred just the contrary. In the second cycle, the $\mathrm{pH}$ values were higher than in the first cycle, regardless of how the hydrogel was implemented in the soil (Figure 2C).

The drained solutions $\mathrm{pH}$ was the lowest in treatments that used magnesium sulfate + MAP and the highest in those that used distilled water. In general, the $\mathrm{pH}$ of the solutions was higher in the second cycle (Figura 2D).

The data obtained in this research suggest that the addition of hydrogel in the soil did not affect significantly the water retention. The results differ from some studies such as the ones of Pereira et al. (2018) and El-Hady et al. (2012), who used hydrogel in the soil in the crop of bean and tomato, in this order. It is worth mentioning that such divergences may be the result of different factors, among which are: the type of the soil and the dose of hydrogel applied. In their cases, the soils are sandy and the dosages that made possible relevant were higher than $1.4 \mathrm{~g} \mathrm{~L}^{-1}$, different from the soil used for this work, which has a clayey texture and a high level of organic matter.

Results similar to these were also observed as in the studies of Pontes Filho et al. (2018), who during the analysis of the establishment of seedlings in Tamboril in two light levels and ten hydrogel dosages (ranging from 0.0 and $6.0 \mathrm{~g} \mathrm{~L}^{-1}$ ) found the above-ground dry weight to increase from the $2,0 \mathrm{~g} \mathrm{~L}^{-1}$ dosages under the sunlight and it was concluded that even though there was a response from the species to the hydrogel dosages, the benefits of polymers did not get so clear in the conditions that the study was carried out.

The high EC in the drainage solutions in treatments containing MS + MAP is due to the high salinity of the solution added to the soil. However, the increase of the EC in the second cycle must be the result of the driving of the soil ions, since the magnesium sulfate is dissociated in anions of $\mathrm{SO}_{4}^{-} \mathrm{e} \mathrm{Mg}^{2+}$ and the MAP has the ammonium ion in its composition $\left(\mathrm{NH}_{4}^{+}\right)$, which is changed into nitrate $\left(\mathrm{NO}_{3}^{-}\right)$under biological action.

Considering the richness of basic cations in the analyzed soil (observed in the chemical analysis of the soil), greater leaching of nutrients occurred, especially in the second cycle, when nitrate concentrations were possibly higher. Ros et al. (2017) corroborates such affirmation when he mentioned in his article that ammonium concentration levels decreased and got close from 0 to 7 in 21-days cultivation of cedar and such decrease matched the increase of nitrate concentration levels.

Nitrate, just like the sulfate, may be used as accompanying ions for basic cations present in the soil solution, making its leaching easier. On the other hand, in the treatment using distilled water, whose EC is found to be low, this ion leaching is not favored, especially as the cycles go by.

The $\mathrm{pH}$ data of the leached solutions correlate with those of the EC, in a manner that the added treatment of the MS + MAP solution also presented a lower $\mathrm{pH}$, as well as the treatment with urea in the second cycle. This is again the result of the $\mathrm{N}$ transformation in the soil, since, during the transformation from ammonium to nitrate, the release of four $\mathrm{H}+$ occurs, resulting in the acidification of the medium. In the case of urea, however, the same also happens in a second stage.

In the first stage, urea is changed into ammonium by the remotion of ions $\mathrm{H}^{+}$from the solution and later release them doubled in the nitrification reactions (Gargantini \& Catani, 1957). This explains the increased $\mathrm{pH}$ in urea and MS + MAP treatments when compared to the one with distilled water.

In the case of the additional witness (hydrogel free), it was generally found that the $\mathrm{pH}$ and $\mathrm{EC}$ did not differ from the treatments containing hydrogel that received distilled water or from the treatments with a diluted and concentrated hydrogel that received the urea solution.

This result is consistent with the previous ones that showed the greatest influence of MS + MAP in the EC and pH of the leached solution, especially when the hydrogel was concentrated and thus had less contact with the solution added to the soil.

\section{Conclusions}

Magnesium sulfate and monoammonium phosphate solutions negatively reduced the hydrogel capacity to absorb water.

When hydrogel is added to the soil, its water absorption efficiency is reduced regardless of the fertilizer solutions added.

Changes in $\mathrm{pH}$ and $\mathrm{EC}$ of leached solutions evidenced the salinity of fertilizer solutions.

Therefore, it is important that more researches are conducted using higher volumes of soil and more polymer dosages so that the effects of the fertilizers can be better estimated under water retention when the hydrogel is in contact with the soil. 


\section{Acknowledgments}

To the master's degree program from Universidade Estadual Vale do Acaraú (UVA) for the logistics support and infrastructure, also to the Coordenação de Aperfeiçoamento de Pessoal de Nivel Superior (CAPES) (Higher Level Staff Development Coordination) for granting a scholarship to the first author.

\section{Conflict of interests}

The authors declare that there is no conflict of interests regarding the publication of this paper.

\section{References}

Azevedo, T. L. F., Bertonha, A., Freitas, P. S. L., Gonçalves, A. C. A., Rezende, R., Dallacort, R., \& Bertonha, L. C. (2006). Retenção de soluções de sulfatos por hidrogel de policrilamida. Acta Scientiarum Agronomy, 28(2), 287-290. https://doi.org/10.4025/actasciagron.v28i2.1131

Bowman, D. C., Evans, R. Y., \& Paul, J. L. (1990). Fertilizer salts reduce hydration of polyacryamide gels and physical properties of gel-amended container. Journal American Society Horticultural Science, 115, 382-386. https://doi.org/10.21273/JASHS.115.3.382

Dąbrowska, J., \& Lejcuś, K. (2012). Characteristics of selected properties of superabsorbents. Infrastructure and Ecology Rural Areas, 3, 59-68.

El-Hady, O. A., Shaaban, S. M., \& Wanas, S. H. A. (2012). Effect of hydrogels and organic composts on soil hydrophysical properties and on production of tomato. Acta Horticulturae, 933, 115-122. https://doi.org/10.17660/ActaHortic.2012.933.12

Fajardo, L., Rodríguez, J. P., González, V., \& Briceño-Linares, J. M. (2013). Restoration of a degraded tropical dry forest in Macanao, Venezuela. Journal of Arid Environments, 88, 236-243. https://doi.org/10.1016/j.jaridenv.2012.08.009

Gargantini, H., \& Catani, R. A. (1957). Determinação do período de tempo para amonificação e nitrificação de diversos fertilizantes nitrogenados. Bragantia, 16(19), 261-268. https://doi.org/10.1590/S000687051957000100019

Głowińska, A., Trochimczuk, A. W., \& Jakubiak-Marcinkowska, A. (2019). Novel acrylate/organophosphorusbased hydrogels for agricultural applications. New outlook and innovative concept for the use of 2(methacryloyloxy)ethyl phosphate as a multi-purpose monomer. European Polymer Journal, 110, 202-210. https://doi.org/10.1016/j.eurpolymj.2018.11.020

Guilherme, M. R., Aouada, F. A., Fajardo, A. R., Martins, A. F., Hasija, V., Sharma, K., ..., \& Sharma, V. (2018). Green synthesis of agar/Gum Arabic based superabsorbent as an alternative for irrigation in agriculture. Vacuum, 157, 458-464. https://doi.org/10.1016/j.vacuum.2018.09.012

Johnson, M. S. (1984). The effects of gel-forming polyacrylamida on moisture in sandy soil. Journal of the Science of Food and Agriculture, 35, 1196-1200. https://doi.org/10.1002/jsfa.2740351110

Kalinoski, R. M., \& Shi, J. (2019). Hydrogels derived from lignocellulosic compounds: Evaluation of the compositional, structural, mechanical and antimicrobial properties. Industrial Crops \& Products, 128, 323330. https://doi.org/10.1016/j.indcrop.2018.11.002

Moghadam, H. R. T., Zahedi, H., \& Ghooshchi, F. (2011). Oil quality of canola cultivars in response to water stress and super absorbent polymer application. Pesquisa Agropecuária Tropical, 41, 579-586. https://doi.org/10.5216/pat.v41i4.13366

Pathak, V. M., \& Kumar, N. (2017). Dataset on the superabsorbent hydrogel synthesis with $\mathrm{SiO}_{2}$ nanoparticle and role in water restoration capability of agriculture soil. Data in Brief, 13, 291-294. https://doi.org/10.1016 / j.dib.2017.05.046

Pereira, J. S., Olszevski, N., \& Silva, J. C. da. (2018). Retenção de água e desenvolvimento do feijão caupi em função do uso de polímero hidrorretentor no solo. Revista Engenharia na Agricultura, 26(6), 582-591. https://doi.org/10.13083/reveng.v26i6.857

Pontes Filho, R. A., Gondim, F. A., \& Costa, M. C. G. (2018). Seedling growth of tree species under doses of hydrogel and two levels of luminosity. Revista Arvore, 42, 1-9. https://doi.org/10.1590/180690882018000100012 
Ros, C. O. da, Silvestrin, T. B., Somavilla, L., Perrando, E. R., \& Silva, R. F. da. (2017). Perdas de Nutrientes por Lixiviação na Produção de Mudas de Cedro Australiano. Floresta Ambiental, 24, 1-10. https://doi.org/10.1590/2179-8087.008116

Ruthrof, K. X., Douglas, T. K., Calver, M. C., Barber, P. A., Dell, B., \& Hardy, G. E. (2010). Restoration treatments improve seedling establishment in a degraded Mediterranean type Eucalyptus ecosystem. Australian Journal of Botany, 58, 646-655. https://doi.org/10.1071/BT10211

Sartore, L., Vox, G., \& Schettini, E. (2013). Preparation and performance of novel biodegradable polymeric materials based on hydrolyzed proteins for agricultural application. Journal of Polymers and the Environment, 21, 718-725. https://doi.org/10.1007/s10924-013-0574-2

Wang, Y. T., \& Gregg, L. L. (1990). Hydrophilic polymers - Their response to soil amendments and effect on properties of soilless potting mix. Journal American Society Horticultural Science, 115, 943-948.

\section{Copyrights}

Copyright for this article is retained by the author(s), with first publication rights granted to the journal.

This is an open-access article distributed under the terms and conditions of the Creative Commons Attribution license (http://creativecommons.org/licenses/by/4.0/). 